\title{
Bibliographic summary about aquatic parasitoids
}

\section{Carlos Henrique Marchiori*}

Biological Sciences, Parasitology, Federal Institute Goiano, Goiânia, Brazil

Received: 04 January, 2020
Accepted: 12 March, 2020

Published: 13 March, 2020

*Corresponding author: Dr. Carlos Henrique Marchiori, Biological Sciences, Parasitology, Federal Institute Goiano, Goiânia, Brazil,

E-mail: chmarchiori@yahoo.com.br

Keywords: Hymenoptera; Characteristics; Parasitism; Brazil; World

https://www.peertechz.com

1 - - - - - - - - - - - - - -

(D) Check for updates

\section{Abstract}

Parasitoids are responsible for reducing the populations of insects that proliferate on various substrates. Evaluation of these species for natural control over these insects is important for enabling studies that aim towards subsequent selection of species for use in biological control programs. This manuscript consists of the elaboration of a bibliographic summary of the parasitoids of Parasitica Hymenoptera) collected in aquatic environments. A bibliographic research was carried out that contained published works on the following aspects: The conservative, Parasitic Hymenoptera characteristics, main superfamilies and families and studies carried out and main genera or species, from November 2019 to January 2020. All species of aquatic parasitoids belong to the order Hymenoptera.

\section{Intrdocution}

A conservative approach has been adopted in this study [1], such that only species for which unequivocal evidence exists that they spend at least some of their life in water are included. This includes species in which female adults enter the water to search for hosts, those with endoparasitoid larvae inside aquatic larval hosts (even if oviposition is terrestrial); and those in which freshly eclosed adults must travel to the water's surface following pupation (even if they develop inside stems of emergent vegetation). Only described species with known hosts are included, except for a few described species that lack host records, but belong to genera that are unquestionably monophyletic and have a clear host range that includes only aquatic hosts. Parasitoids that develop exclusively on terrestrial stages of aquatic insects are excluded (e.g. in pupae of whirligig beetles or spongilla-flies) [1].

\section{Methods}

This study, which consisted of the composition of a bibliographic summary of the main groups of parasitoids of the Order Hymenoptera (Parasitica Hymenoptera) collected in the aquatic environment, a bibliographic research was carried out that contained published works on the following aspects: Hymenoptera Characteristics, Parasitic Hymenoptera Characteristics, Main Superfamilies and Families and Studies carried out and Main genera or species, from November 2019 to January 2020.
Parasitic hymenoptera characteristics, main superfamilies and families and studies carried out and main genera or species

Aquatic Hymenoptera are known from six superfamilies and 11 families. The two largest families, Ichneumonidae and Braconidae, have the two greatest numbers of aquatic species: 39 and 26, respectively. Within the Ichneumonidae, species in at least five genera appear to be exclusively aquatic: Agriotypus Curtis (Agriotypinae) on Trichoptera (kirby) and Rhachioplex Bischoff (Campopleginae), Pseuderipternus Viereck, Tanychela \& Townes (both Cremastinae) and Apsilops Förster (Cryptinae) on Lepidoptera. The braconid genus Ademon Haliday (Opiinae) is almost exclusively associated with Hydrellia spp. larvae in emergent vegetation. Next in richness of aquatic species are two families of egg parasitoids: Trichogrammatidae (22) and Scelionidae (17). Centrobiopsis Girault, Hydrophylita Ghesquie`re and Prestwichia Lubbock (Trichogrammatidae) have only aquatic species and Pseudanteris Fouts, Thoron Haliday, Thoronella Masner \& Tiphodytes Bradley (Scelionidae) are all aquatic. The remaining families have 12 or fewer aquatic species recorded within each of them. Caraphractus cinctus Walker (Mymaridae), a parasitoid of dytiscid beetle eggs, has been studied extensively and is known to swim with its wings and mate inside submerged eggs [1].

The definition of aquatic Hymenoptera adopted here is that of Hagen 1996 [2,3], which includes all Hymenoptera 
species that parasitize any life stage of aquatic insects. Most of these species belong to the families Eulophidae, Mymaridae, Trichogrammatidae and Scelionidae. In Brazil, the only Hymenoptera egg parasitoid of Odonata reported is Hydrophylita lestesi [3] (Trichogrammatidae), which was observed parasitizing eggs of Lestes sp. (Lestidae) on leaves of Hedychium coronarium [3]. Additional information found in the literature indicates Lathromeroidea sp. (Trichogramatidae) as a parasitoid of gerrid eggs [4] and Trichogramma species parasitizing eggs of Sialidae (Megaloptera) [5,6].

The life history and host-searching behaviour of Apsilops japonicas Yoshida, Kakuma, Nagasaki, Osamu, Hirayama \& Tomoko, 2011 parasitizing the aquatic moth Neoshoenobia testacealis Hampson (Lepidoptera: Crambidae) were studied in the field and in the laboratory in Japan. Moth larvae initially mine the floating leaves of the yellow water lily, later boring into the petiole and pupating in the petiole underwater. While the wasps did not attack leaf-mining larvae, they were idiobiont ectoparasitoids of the pupae or mature larvae of $N$. testacealis in the petioles. The wasps did not swim with their wings or legs when searching for hosts underwater, they walked down leaf petioles into the water. It is presumed that the wasps overwinter as adults. The laboratory observations suggested that the female wasps could not detect the host presence in the petiole from the floating leaves and they randomly searched for hosts by probing with their ovipositors underwater [1].
A summary of the known species of aquatic Hymenoptera is presented. In total, 150 species from 11 families are recognized as aquatic ( $0.13 \%$ of the total described species). This number is likely an underestimate, because of the high percentage of undescribed species and a lack of knowledge of host range and behaviour for most species. All aquatic Hymenoptera are parasitoids. Many species have relatively dense pubescence to trap air and elongate, tarsal claws to grip the substrate, when underwater. Most species are known from the Holarctic and Oriental regions, but this is likely an artefact caused by lack of knowledge of other regions of the world. Aquatic behaviour has evolved independently at least 50 times within the order [7].

Querino \& Hamada [6] (Figures 1-7) investigated the tritrophic interaction Argia insipida Hagen in Selys, the Trichogrammatidae egg parasitoid Pseudoligosita longifrangiata (Viggiani) and the host plant Tonina fluviatilis (Eriocaulacea), which is a substrate for egg deposition of A. insipid, was investigated. The study locality was a stream with rapids where macrophytes such as T. fluviatilis grow. Information on aquatic egg parasitoids is scarce. This is the first record of egg parasitism of $A$. insipida by $P$. longifrangiata in Brazil, and the first record of occurrence of $P$. longifrangiata in the country [7].

The nature of this relation, however, has to be deeper studied in order to permit a better evaluation of the impact of these parasitoids on the insect pest population. Since these parasitoids are natural enemies of insect pests, the feasibility

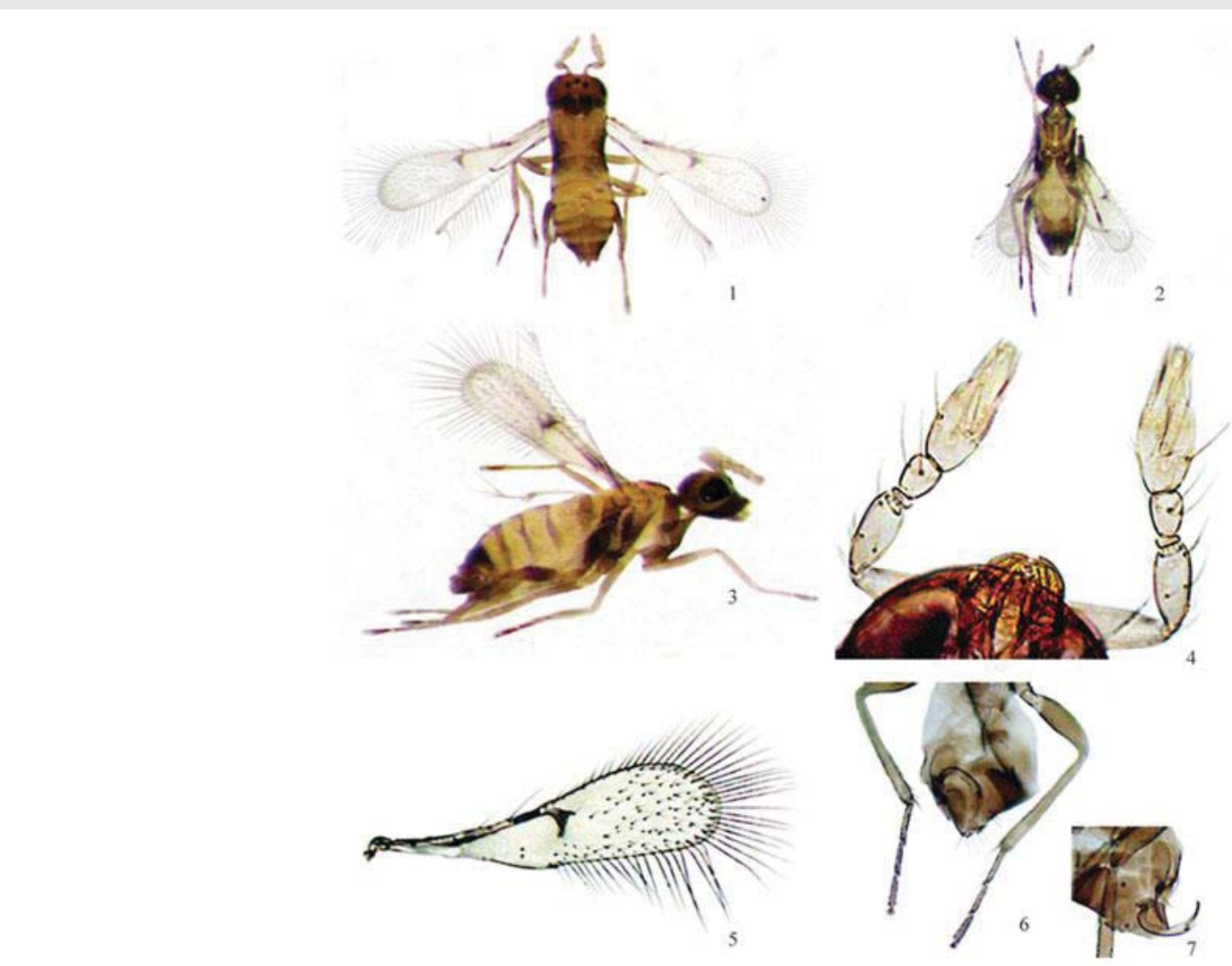

Figures 1-7: Pseudoligosita longifrangiata, adult male. 1. Dorsal view. 2. Ventral view. 3. Lateral View. 4. Antenna. 5. Forewing. 6. Genitalia, vental view. 7. Genitalia, lateral view.Source: [6]. 
of their use as biological control agents on the fig is an encouraging possibility $[8,9]$.

\section{References}

1. Bennett AMR (2008) Global diversity of hymenopterans (Hymenoptera; Insecta) in freshwater. Hydrobiologia 595: 529-534. Link: https://bit.ly/2TMQMul

2. Hagen KS (1996) Aquatic Hymenoptera. In Merritt R W, Cummins K W (eds) An introduction to the aquatic insects of North America. Debuque, lowa, Kendall/ Hunt Publishing Company 862.

3. da Costa LA (1960) Sôbre alguns microhimenópteros aquáticos (Chalcidoidea, Eulophidae e Trichogrammatinae). Arq Inst Biol 27: 197-200.

4. Henriquez NP, Spence JR (1993) Studies of Lathromeroidea sp. (Hymenoptera Trichogrammatidae), a parasitoid of gerrid eggs. Can Entomol 125: 693702. Link: https://bit.ly/2W6Piwc

5. Azam KM, Anderson NH (1969) Life history and habits of Sialis rotunda and S. californica in Western Oregon. Ann Entomol Soc Am 62: 549-558. Link: https://bit.ly/38ECLCY

6. Querino RB, Hamada N (2009) An aquatic microhymenopterous egg-parasitoid of Argia insipida Hagen in Selys (Odonata: Coenagrionidae) and biological bservations in the Central Amazon, Brazil. Neotrop Entomol 38: 346-351. Link: https://bit.ly/33a0Qi8

7. Tomoko H, Takuma Y, Osamu N (2014) The life history and host-searching behaviour of the aquatic parasitoid wasp Apsilops japonicus (Hymenoptera: Ichneumonidae), a parasitoid of the aquatic moth Neoshoenobia testacealis (Lepidoptera: Crambidae). J Nat Hist 48: 959-967. Link: https://bit.ly/2Q7Fkak

8. Marchiori CH (2013) Fragment agricultural pests of some parasitoids collected in Southern Goiás and Southern Minas Gerais, Brazil. Annals of West University of Timişoara Ser Biology 16: 141-146. Link: https://bit.ly/2xwNliB

9. Barnard PC (1977) Sialis nigripes Pictet (Megaloptera, Sialidae), an alder-fly new to Britain and Ireland. Entomol Gazette 28: 269-274. Link: https://bit.ly/2wLbxgJ

\section{Discover a bigger Impact and Visibility of your article publication with} Peertechz Publications

\section{Highlights}

* Signatory publisher of ORCID

* Signatory Publisher of DORA (San Francisco Declaration on Research Assessment)

* Articles archived in worlds' renowned service providers such as Portico, CNKI, AGRIS, TDNet, Base (Bielefeld University Library), CrossRef, Scilit, J-Gate etc.

* Journals indexed in ICMJE, SHERPA/ROMEO, Google Scholar etc.

* OAI-PMH (Open Archives Initiative Protocol for Metadata Harvesting)

* Dedicated Editorial Board for every journal

* Accurate and rapid peer-review process

* Increased citations of published articles through promotions

* Reduced timeline for article publication

Submit your articles and experience a new surge in publication services (https://www.peertechz.com/submission).

Peertechz journals wishes everlasting success in your every endeavours.

Copyright: @ 2020 Marchiori $\mathrm{CH}$. This is an open-access article distributed under the terms of the Creative Commons Attribution License, which permits unrestricted use distribution, and reproduction in any medium, provided the original author and source are credited. 